
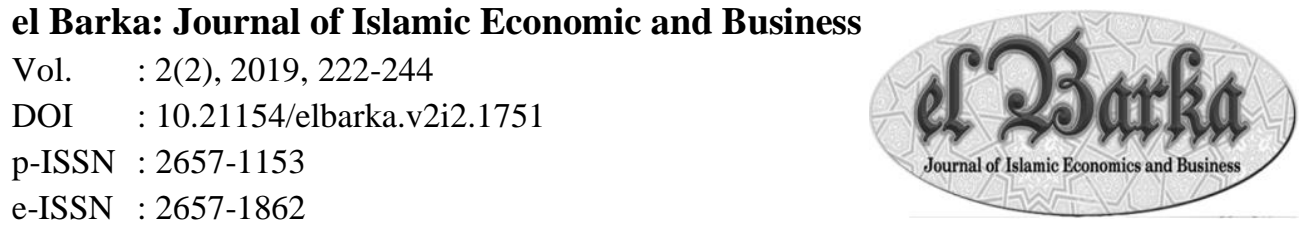

\title{
PENGARUH CORPORATE GOVERNANCE DALAM MEMPREDIKSI BIAYA EKUITAS DENGAN PENDEKATAN MODEL OHLSON
}

\author{
Muhammad Rivandi \\ Sekolah Tinggi Ilmu Ekonomi KBP \\ email: muhammadrivandi@akbpstie.ac.id

\section{Marlina Marlina} \\ Sekolah Tinggi Ilmu Ekonomi KBP \\ email: marlina@akbpstie.ac.id
}

\begin{abstract}
Cost of equity a concept of cost in determining the real cost that must be borne by the company to obtain funds from a source or use of capital from each source of funds, then determine the average cost of capital of all funds used by the company. The method used in the measurement of equity costs is the Ohlson model. Research objectives to prove empirically the Effect of Corporate Governance in Predicting Equity Costs with the Ohlson Model Approach. Research population of manufacturing companies on the Indonesia Stock Exchange. The sample used using porposive sampling techniques amounted to 30 companies. The analysis method used uses a panel regression model. Based on the test results, it is empirically proven that (1) Family Ownership does not affect the cost of Equity, (2) Institutional Ownership negatively affects the cost of equity, (3) The Independent Board of Commissioners does not affect the cost of equity.
\end{abstract}

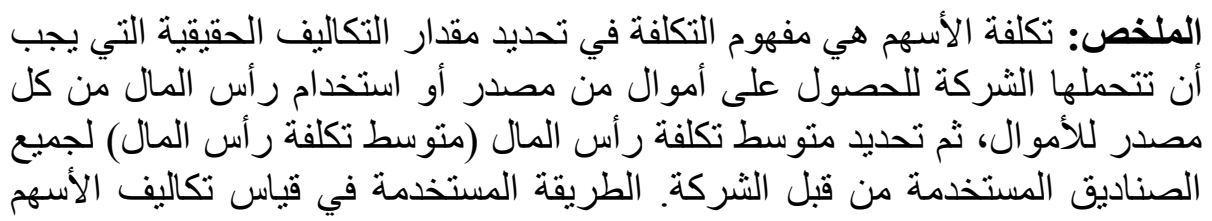




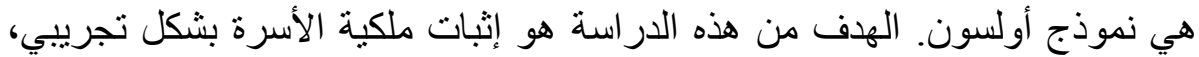

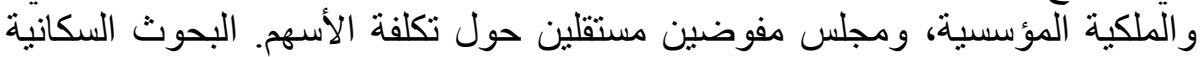
لهذا البحث شركات في بورصة إندونيسيا. كانت العينة المستخدمة تقنية أخذ عينات

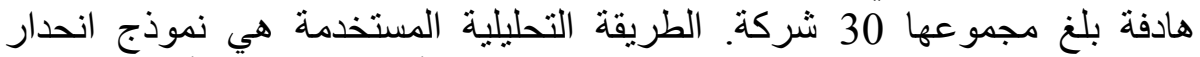

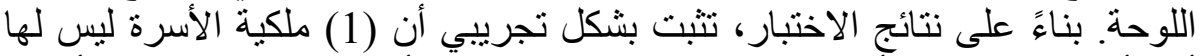

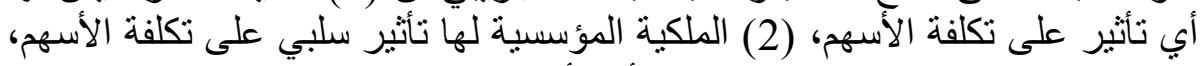

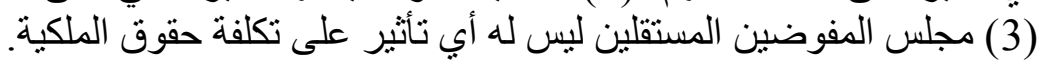

Abstrak: Biaya ekuitas sebuah Konsep biaya dalam menentukan besarnya biaya secara riil yang harus ditanggung oleh perusahaan untuk memperoleh dana dari suatu sumber atau penggunaan modal dari masing-masing sumber dana, untuk kemudian menentukan biaya modal rata-rata (average cost of capital) dari keseluruhan dana yang dipergunakan perusahaan. Metode yang digunakan didalam pengukuran biaya ekuitas adalah model Ohlson. Tujuan penelitian untuk membuktikan secara empiris Kepemilikan Keluarga, Kepemiikan Institusional, dan Dewan Komisaris Independen Terhadap Biaya Ekuitas. Populasi penelitian perusahaan manufaktur di Bursa Efek Indonesia. Sampel yang digunakan mengunakan teknik porposive sampling berjumlah 30 perusahaan. Metode Analisis yang digunakan menggunakan model regresi panel. Berdasrkan hasil pengujian membuktikan secara empiris bahwa (1) Kepemilikan Keluarga tidak berpengaruh terhadap biaya Ekuitas, (2) Kepemilikan Institusional berpengaruh negatif terhadap biaya ekuitas, (3) Dewan Komisaris Independen tidak berpengaruh terhadap biaya ekuitas.

Keywords: Corporate Governance; Biaya Ekuitas

\section{PENDAHULUAN}

Biaya dibagi dalam arti luas dan arti sempit yaitu : dalam arti luas, biaya merupakan pengorbanan sumber ekonomi yang diukur dalam satuan uang, yang telah terjadi atau kemungkinan akan terjadi untuk tujuan tertentu, sedangkan dalam arti sempit, biaya merupakan pengorbanan sumber ekonomi untuk memperoleh aktiva. Pengeluaran 
biaya yang dikeluarkan perusahaan untuk tujuan kelanjutan perusahaan dalam melakukan semua kegiatan aktivitas perusahaan seperti kegiatan operasional, kegiatan investasi dan kegiatan pendanaan perusahaan. Biaya yang dikeluarkan perusahaan untuk keberlangsungan yang hidup perusahaan dalam mengelola dana perusahaan. ${ }^{1}$

Biaya yang dikeluarkan tidak terlepas dari biaya ekuitas (biaya modal) yang dikeluarkan perusahaan untuk mendanaai semua kegiatan aktivitas perusahaan. Biaya ekuitas adalah sebuah konsep yang dipengaruhi oleh beberapa faktor ekonomi dan jumlah biaya yang diukur sebagai tingkat bunga dari berbagai sumber modal yang masing-masing ditimbang menurut peranannya dalam struktur modal dan permodalan yang digunakan oleh perusahaan. Biaya yang harus dikeluarkan perusahaan untuk memberi kepuasan pada investornya pada tingkat risiko tertentu. Konsep biaya ekuitas dimaksudkan untuk dapat menentukan besarnya biaya secara riil yang harus ditanggung oleh perusahaan untuk memperoleh dana dari suatu sumber atau penggunaan modal dari masing-masing sumber dana, untuk kemudian menentukan biaya modal rata-rata (average cost of capital) dari keseluruhan dana yang dipergunakan perusahaan tersebut. ${ }^{2}$

Konsep dari biaya ekuitas dibutuhkan model untuk mengukur biaya ekuitas yaitu digunakan Model Ohlson, dimana Model ini digunakan untuk mengestimasi dan memprediksi nilai perusahaan 2008).

${ }^{1}$ Herawati, Akuntansi Biaya LKMS (Padang: Universitas Bung Hatta Press,

${ }^{2}$ D. M. Chancera, "Biaya Modal Ekuitas pada Perusahaan Manufaktur yang Terdaftar di Bursa Efek Indonesia ( BEI ) Tahun 2008-2009”. Skripsi Fakultas Ekonomi Universitas Diponegoro (2011). 
dengan mendasarkan pada nilai buku ekuitas ditambah dengan nilai tunai dari laba abnormal. Model ini sangat berguna dalam melakukan pengukuran dalam biaya ekuitas. Pengukuran model ohlson jarang digunakan dalam melakukan pengukuran biaya ekuitas. Perusahaan lebih sering menggunakan model penilaian pertumbuhan konstan (constant growth valuation model), capital asset pricing model (CAPM), tetapi model Ohlson juga dapat dipertimbangkan dalam melakukan pengukuran biaya ekuitas. Pada dasarnya memakai model Ohlson untuk mengestimasi biaya modal ekuitas, dengan menggunakan estimasi laba per lembar saham yang di publikasikan oleh Value Line. Di Indonesia publikasi data forecast laba per saham tidak ada. Oleh karena itu, untuk estimasi laba per saham yang digunakan dalam penelitian ini adalah dengan menggunakan random walk model. ${ }^{3}$

Agency Theory, dapat menjelaskan bagaimana pihak-pihak yang terlibat dalam perusahaan akan berperilaku, karena pada dasarnya antara agent dan principal memiliki kepentingan yang berbeda yang menyebabkan terjadinya konflik keagenan (agent conflict). Pada dasarnya, konflik keagenan terjadi karena adanya pemisahan antara kepemilikan dan pengendalian perusahaan. Adanya konflik kepentingan antara investor dan manajer menyebabkan munculnya Agency Cost yaitu biaya monitoring (monitoring cost) yang dikeluarkan oleh principal seperti auditing, penganggaran, sistem pengendalian dan kompensasi, biaya perikatan (bonding expenditure)

${ }^{3}$ D. M. Chancera, "Biaya Modal Ekuitas pada Perusahaan Manufaktur yang Terdaftar di Bursa Efek Indonesia ( BEI ) Tahun 2008-2009”. 
yang dikeluarkan oleh agent dan kerugian residual berkaitan dengan divergensi kepentingan antara principal dan agent. ${ }^{4}$

Pengawasan dari biaya ekuitas dibutuhkanlah Corporate Governance dalam melakukan pengawasan. Corporate governance dapat ditelusuri dari pengembangan agency theory yang mencoba menjelaskan bagaimana pihak-pihak yang terlibat dalam perusahaan (manajer, pemilik perusahaan dan kreditor) akan berperilaku, karena mereka pada dasarnya mempunyai kepentingan yang berbeda. Masalah corporate governance timbul karena terjadi pemisahan antara kepemilikan dan pengendalian perusahaan. Pemisahan antara fungsi kepemilikan dan pengelolaan perusahaan menimbulkan kemungkinan terjadinya agency problem yang dapat menyebabkan agency conflict, yaitu konflik yang timbul sebagai akibat keinginan manajemen (agent) untuk melakukan tindakan yang sesuai dengan kepentingannya yang dapat mengorbankan kepentingan pemegang saham (principal) untuk memperoleh return dan nilai jangka panjang perusahaan.

Perusahaan yang dikendalikan oleh keluarga mempunyai struktur yang menyebabkan berkurangnya konflik agensi antara pemegang saham dan kreditur, di mana kreditur menganggap kepemilikan keluarga lebih melindungi kepentingan kreditur. Perusahaan yang dikendalikan keluarga, masalah agensinya lebih kecil karena berkurangnya konflik antara principal dan agent. Jika kepemilikan keluarga lebih efisien, maka pada perusahaan dengan

${ }^{4}$ M. C. Jensen, dan W. H. Meckling, "Theory of the firm: Managerial behavior, agency costs and ownership structure", Journal of Financial Economics, 3(4) (1976), 305-360. 
kepemilikan keluarga yang tinggi pengelolaan laba yang oportunis dapat dibatasi. ${ }^{5}$

Hasil penelitian yang dilakukan Rebecca \& Siregar membuktikan bahwa kepemilikan keluarga memiliki pengaruh signifikan positif terhadap biaya ekuitas perusahaan. Hal ini dapat disebabkan karena perusahaan dengan kepemilikan keluarga munculnya agency problem yaitu Pemegang saham mayoritas dan Pemegang saham minoritas. Risiko informasi menjadi lebih besar ketika pemegang saham mayoritas dan memiliki kontrol di dalam perusahaan. Oleh karena itu return yang diinginkan investor menjadi lebih tinggi dan meningkatkan biaya ekuitas. ${ }^{6}$

Excess control yang ditemukan dalam perusahaan keluarga menyebabkan turunnya nilai perusahaan sehingga biaya ekuitas perusahaan pun akan meningkat. Kepemilikan keluarga diyakini berpengaruh positif terhadap biaya ekuitas karena dalam kepemilikan keluarga mempunyai pengaruh yang besar, sehingga dapat memberikan peluang kepada pemegang saham mayoritas untuk melakukan ekspropriasi terhadap pemegang saham minoritas. ${ }^{7}$ Kepemilikan keluarga berpengaruh positif terhadap biaya ekuitas. Perusahaan dengan kepemilikan keluarga sebagai pemegang saham

${ }^{5}$ Arifin, "Peran Akuntan dalam Menegakkan Prinsip Good Corporate Governance pada Perusahaan di Indonesia (Tinjauan Perspektif Teori Keagenan)", Jurnal Ekonomi Universitas Diponegoro, (2005), 1-52.

${ }^{6}$ Y. Rebecca, dan S. V. Siregar, "Pengaruh Corporate Governance Index, Kepemilikan Keluarga, dan Kepemilikan Institiusional terhadap Biaya Ekuitas dan Biaya Utang: Studi Empiris pada Perusahaan Manufaktur yang Terdaftar di BEI", Simposium Nasional Akuntansi 13, (2004), 1-28.

${ }^{7}$ O. Guedhami, dan D. Mishra, "Excess control , Corporate Governance , and Implied Cost of Equity: An International Evidence", The Financial Review, 44(4), (2006), 489-524. 
mayoritas memiliki biaya ekuitas yang lebih tinggi dibandingkan perusahaan lainnya. Berdasarkan Teori dan hasil penelitian dapat diturunkan hipotesis bahwa Kepemilikan Keluarga Berpengaruh positif terhadap Biaya Ekuitas. ${ }^{8}$

Investor institusional diyakini memiliki kemampuan yang lebih baik untuk memonitor tindakan manajemen dibandingkan dengan investor individual dimana investor institusional tidak mudah diperdaya dengan manipulasi yang dilakukan oleh manajemen. ${ }^{9}$ Selain itu, investor Institusional yang umumnya berperan sebagai fiduasari, memiliki insentif yang lebih besar untuk memantau tindakan manajemen dan kebijakan perusahaan. Kondisi ini dapat menyebabkan berkurangnya perilaku opportunistik manajemen yang mengarah pada biaya ekuitas yang lebih rendah. ${ }^{10}$

Menurut Suntoso ${ }^{11}$ dan Sari ${ }^{12}$ bahwa Kepemilikan Institusional mempunyai pengaruh negatif dan signifikan terhadap biaya hutang, semakin tinggi kepemilikan Institusional maka di harapkan semakin

${ }^{8}$ J. Yao, dan S. Y. Sun, "Ownership Structure and Cost of Equity Capital in East Asian Corporations", School of Accounting and Finance, The Hong Kong Polytechnic University, (2008).

${ }^{9}$ Juniarti, dan A. A. Sentosa, "Pengaruh Good Corporate Governance, Voluntary Disclosure terhadap Biaya Hutang (Costs of Debt)", Jurnal Akuntansi Dan Keuangan, 11(2), (2009), 88-100.

${ }^{10}$ M. Rivandi, "Pengaruh Enterprise Risk Management Disclosure dan Corporate Governance terhadap Nilai Perusahaan", Jurnal Benefita, 3(2), (2018), 137.

${ }^{11}$ Susanto, "Struktur Kepemilikan Saham dan Kondisi Keuangan Perusahaan Pengaruhnya Terhadap Kebijakan Hutang (Studi pada Perusahaan Manufaktur di Pasar Modal Indonesia)", Neo-Bisnis, 5(1), (2011).

${ }^{12}$ P. A. Sari, "Pengaruh Struktur Corporate Governance terhadap Cost of Equity Capital", Skripsi Fakultas Ekonomi Universitas Sebelas Maret Surakarta, (2009), 1-134. 
kuat kontrol terhadap perusahaan dimana dapat mengurangi agency cost pada perusahaan serta penggunaan hutang dalam struktur ekuitas.

Menurut Tarjo kepemilikan Institusional berpengaruh positif terhadap Cost of Equity Capital. ${ }^{13}$ Hal ini memperlihatkan bahwa pemilik mayoritas tidak melakukan ekspropriasi karena takut pasar saham dan pemegang saham minoritas mendiskon harga pasar saham. Sehingga pemilik mayoritas menekan manajer untuk menginformasikan mengenai perusahaan kepada publik sesuai dengan realita yang ada walaupun itu perlu biaya besar. Hal ini sesuai dengan pendapat Ashboug bahwa investor institusional memiliki kemungkinan untuk tidak melakukan monitoring terhadap manajemen karena tindakan tersebut membutuhkan biaya yang besar. ${ }^{14}$

Tindakan pengawasan prilaku manajemen membutuhkan biaya yang cukup besar, penelitiannya menunjukkan bahwa kepemilikan saham oleh institusional berdampak positif terhadap biaya ekuitas perusahaan. ${ }^{15}$ Pasar modal yang likuid mengurangi insentif investor institusional untuk memonitor perusahaan karena akan lebih murah bagi investor institusional untuk menjual kembali sahamnya ketika kinerja perusahaan buruk dibandingkan harus memonitor perusahaan. Penyebabnya adalah muncul masalah free rider yaitu ketika manfaat dari tindakan monitoring berlaku terhadap semua pemegang saham. Berdasarkan teori dan Hasil penelitian dapat diturunkan hipotesis

${ }^{13}$ Tarjo, "Pengaruh Konsentrasi Kepemilikan Institusional dan Leverage terhadap Manajemen Laba, Nilai Pemegang Saham serta Cost of Equity Capital”, Jurnal Ekonomi Universitas Trunojoyo Bangkalan Madura, (2006).

${ }^{14}$ H. Ashbough, D. W. Collins, dan L. Ryan, Collins, "Corporate Governance and the Cost of Equity Capital”, SSRN Electronic Journal, (October, 2004), 49.

${ }^{15}$ H. Ashbough, D. W. Collins, dan L. Ryan, Collins. 
bahwa kepemilikan Institusional berpengaruh positif terhadap Biaya Ekuitas. $^{16}$

Berdasarkan Peraturan Ototitas Jasa Keuangan No.33 (2014) Dewan Komisaris Independen merupakan anggota Dewan Komisaris yang berasal dari luar Emiten atau Perusahaan Publik dan memenuhi persyaratan sebagai Komisaris Independen. Fungsi dewan komisaris independen untuk mengawasi jalannya perusahaan dengan memastikan bahwa perusahaan telah melakukan praktek-praktek transparansi, disclosure, kemandirian, akuntabilitas dan praktek keadilan menurut ketentuan yang berlaku di suatu sistem perekonomian. ${ }^{17}$

Menurut Ashbough menunjukkan bahwa komposisi dewan independen berpengaruh negatif terhadap cost of equity capital, dimana semakin banyak jumlah dewan yang berasal dari luar, fungsi pengawasan yang mereka lakukan akan semakin efektif sehingga dapat meminimalkan tindakan earnings management. Jika tindakan earnings management berkurang, maka risiko agensi juga akan berkurang dan cost of equitycapital menjadi rendah. Penerapan corporate governance yang baik akan menghasilkan biaya ekuitas yang lebih rendah melalui pengurangan biaya monitoring yang dilakukan oleh investor. Hal ini disebabkan investor harus mengeluarkan biaya monitoring untuk

16 Rebecca, dan S. V. Siregar, "Pengaruh Corporate Governance Index, Kepemilikan Keluarga, dan Kepemilikan Institiusional terhadap Biaya Ekuitas dan Biaya Utang: Studi Empiris pada Perusahaan Manufaktur yang Terdaftar di BEI", (2004).

${ }^{17}$ Peraturan Ototitas Jasa Keuangan No.33, ”Direksi dan Dewan Komisaris Emiten atau Perusahaan Publik". Nomor 33 /Pojk.04/2014. Jakarta: Republik Indonesia, (2014). 
memastikan hasil yang diberikan oleh manajemen perusahaan akibat adanya asimetri informasi. ${ }^{18}$

Menurut Sari dan Diyanty bahwa komposisi dewan komisaris independen berpengaruh negatif signifikan terhadap biaya ekuitas. Dewan komisaris independen dianggap telah menjalankan fungsinya dengan baik, salah satunya melakukan pengawasan terhadap manajemen sehingga dapat mengurangi timbulnya konflik keagenan dan asimetri informasi dalam perusahaan. ${ }^{19}$

Penelitian yang dilakukan Sari mengindikasikan banyaknya dewan komisaris independen secara signifikan menurunkan cost of capital perusahaan. ${ }^{20} \mathrm{Hal}$ ini sejalan dengan hasil penelitian Rad bahwa terdapat hubungan negatif dan signifikan antara banyaknya komisaris independen dan cost of capital, hal tersebut mengindikasikan bahwa rekomendasi penunjukkan sepertiga dari anggota dewan komisaris yang merupakan dewan komisaris independen memiliki efek positif pada perusahaan, pengawasan komisaris independen yang efektif dan efisien membantu perusahaan dalam mengurangi cost of capital. Berdasarkan teori dan Hasil penelitian dapat diturunkan hipotesis bahwa komisaris Independen berpengaruh Negatif terhadap Biaya Ekuitas.

${ }^{18}$ H. Ashbough, D. W. Collins, dan L. Ryan, Collins, "Corporate Governance and the Cost of Equity Capital", SSRN Electronic Journal, (October, 2004)

${ }^{19}$ I. C. Sari, dan V. Diyanty, "Pengaruh Efektifitas Dewan Komisaris dan Pengendali Keluarga Terhadap Biaya Ekuitas". Jurnal Ekonomi Universitas Indonesia, (2014).

${ }^{20}$ P. A. Sari, "Pengaruh Struktur Corporate Governance Terhadap Cost of Equity Capital”. Skripsi Fakultas Ekonomi Universitas Sebelas Maret Surakarta, (2009). 1-134. 


\section{METODE PENELITIAN}

Data yang digunakan di dalam penelitian ini adalah data sekunder yaitu data yang diperoleh dari hasil publikasi yang telah dilakukan perusahaan. sumber data diperoleh dari Laporan Annual report perusahaan. Proses dokumentasi pengumpulan data laporan annual report selama tahun pengamatan $2014-2018$.

Populasi pada penelitian adalah semua perusahaan yang terdaftar di Bursa Efek Indonesia. Sedangkan pemilihan sampelnya menggunakan metode purposive sampling, Kriteria yang digunakan adalah (1) Perusahaan Manufaktur yang terdaftar di Bursa efek Indonesia dari tahun 2014 - 2018, (2) Perusahaan yang menerbitkan laporan tahunan dari tahun 2014 - 2018, (3) Perusahaan yang tidak delisting selama periode pengamatan, (4) Perusahaan yang memiliki laba positif. Berdasarkan kriteria purposive sampling, maka sampel perusahaan yang memenuhi kriteria penelitian sebanyak 30 perusahaan dengan observasi penelitian selama 5 tahun, maka jumlah objek observasi sebanyak 150 buah data observasi yang dibutuhkan 


\section{DEFINISI OPERASIONAL VARIABEL \\ Tabel 1 \\ Definisi Operasional Variabel}

\begin{tabular}{|c|c|c|}
\hline No & $\begin{array}{c}\text { Definisi Operasional } \\
\text { Variabel } \\
\end{array}$ & Pengukuran \\
\hline 1 & $\begin{array}{l}\text { Biaya Ekuitas adalah } \\
\text { Sebuah konsep yang } \\
\text { dipengaruhi oleh beberapa } \\
\text { faktor ekonomi dan jumlah } \\
\text { biaya yang diukur sebagai } \\
\text { tingkat bunga dari berbagai } \\
\text { sumber modal yang } \\
\text { masing-masing ditimbang } \\
\text { menurut peranannya dalam } \\
\text { struktur modal dan } \\
\text { permodalan yang } \\
\text { digunakan oleh perusahaan. }\end{array}$ & $\begin{array}{l}\text { Pengukuran biaya ekuitas diukur dengan } \\
\text { menggunakan model Ohlson } \\
\boldsymbol{C O E}=\left(\mathbf{B}_{\mathbf{t}}+\mathbf{x}_{\mathrm{t}+1}-\mathbf{P}_{\mathbf{t}}\right) /\left(\mathbf{P}_{\mathbf{t}}\right) \\
\text { Dimana: } \\
\text { COE=estimasi cost of equity (biaya ekuitas) } \\
\mathrm{Pt}=\text { harga saham pada periode } \mathrm{t} \\
\mathrm{Bt}=\text { nilai buku perlembar saham periode } \mathrm{t} \\
\mathrm{x}_{\mathrm{t}+1}=\text { laba perlembar saham pada periode } \\
\mathrm{t}+1\end{array}$ \\
\hline 2 & $\begin{array}{l}\text { Kepemilikan Keluarga } \\
\text { adalah perusahaan yang } \\
\text { dikendalikan oleh keluarga } \\
\text { mempunyai struktur yang } \\
\text { menyebabkan } \\
\text { berkurangnya konflik } \\
\text { agensi antara pemegang } \\
\text { saham dan kreditur, di } \\
\text { mana kreditur menganggap } \\
\text { kepemilikan keluarga lebih } \\
\text { melindungi kepentingan } \\
\text { kreditur. }\end{array}$ & $\begin{array}{l}\text { Kepemilikan Keluarga } \\
\qquad=\frac{\text { Jumlah Kepemilikan Saham Keluarga }}{\text { Jumlah Saham Beredar }} \times 100\end{array}$ \\
\hline 3 & $\begin{array}{l}\text { Kepemilikan Institusional } \\
\text { adalah kepemilikan saham } \\
\text { perusahaan yang dimiliki } \\
\text { oleh investor Institusional } \\
\text { seperti pemerintah, } \\
\text { perusahaan investasi, bank, } \\
\text { perusahaan asuransi, } \\
\text { Institusi luar negeri, dana } \\
\text { perwalian serta institusi } \\
\text { lainnya. }\end{array}$ & $\begin{array}{l}\text { Kepemilikan Institusioanl } \\
=\frac{\text { Jumlah Saham kepemilikan Institusional }}{\text { Jumlah Saham Beredar }} \times 100\end{array}$ \\
\hline
\end{tabular}




\begin{tabular}{|c|c|c|}
\hline 4 & $\begin{array}{lr}\begin{array}{l}\text { Dewan } \\
\text { Independen } \\
\text { anggota Dewan }\end{array} & \begin{array}{r}\text { Komisaris } \\
\text { adalah }\end{array} \\
\text { yang bomisaris } \\
\text { Emiten atau }\end{array}$ & $\begin{array}{l}\text { Dewan Komisaris Independe } \\
\qquad=\frac{\text { Jumlah dewan Komisaris Indepent }}{\text { Total Jumlah Dewan Komisaris }}\end{array}$ \\
\hline
\end{tabular}

Untuk membuktikan kebenaran hipotesis maka digunakan metode analisis yang dilakukan dengan menggunakan model pengujian hipotesis terlebih dahulu, pengujian kelayakan model dalam penelitian menggunakan 3 pembentukan model. Model regresi panel terdapat tiga model uji kelayakan regresi yang sering digunakan dalam penelitian, yaitu Common Effect Model, Fixed Effect Model dan Random Effect Model. ${ }^{21}$

Pengolahan data dalam penelitian dilakukan dengan menggunakan bantuan program Eviews 9 dengan melakukan analisis menggunakan model regresi panel. Model regresi panel yang digunakan dalam bentuk berganda yang dirumuskan kedalam persamaan dibawah ini

$$
C O E=\beta_{0}+\beta_{1} K K_{i t}+\beta_{2} K I_{i t}+\beta_{2} D K I_{i t}+e
$$

Berdasarkan model Regresi Berganda menjelaskan bahwa COE merupakan Biaya Ekuitas, KK merupakan Kepemilikan Keluarga, KI merupakan Kepemilikan Institusional, DKI merupakan Dewan

${ }^{21}$ W.Winarno, Operational Eviews (Jakarta: Salemba Empat, 2009). 
Komisaris Independen, $a$ dan $\beta_{0}$ merupakan Konstanta, $\beta_{1}-\beta_{3}$ merupakan Koefisien regresi dan terakhir e merupakan error.

\section{HASIL DAN PEMBAHASAN PENGUJIAN UJI KELAYAKAN MODEL REGRESI PANEL}

Pengujian kelayakan model setelah dilakukan pengujian diantara ketiga model regresi panel maka peneliti mengambil kepetusan kelayakan model yang terbaik menggunakan Model Random Effect. Pengujian Random Effect Model dilakukan pengujian Hausman Test. Berdasarkan hasil pengujian hausman test yang telah dilakukan diperolah ringkasan hasil tersebut pada tabel 2 .

\section{Tabel 2 \\ Uji Hausman Test}

Correlated Random Effects - Hausman Test

Equation: Untitled

Test cross-section random effects

\begin{tabular}{lcrc}
\hline \hline & $\begin{array}{c}\text { Chi-Sq. } \\
\text { Test Summary }\end{array}$ & $\begin{array}{r}\text { Chi-Sq. } \\
\text { d.f. }\end{array}$ & Prob. \\
\hline \hline $\begin{array}{l}\text { Cross-section random } \\
\text { Sumber pengolahan data Eviews 2019 }\end{array}$ & 3 & 0.7313 \\
& 1.290737 & &
\end{tabular}

Sesuai dengan hasil pengujian yang telah dilakukan diperoleh nilai prob Cross-secction random sebesar 0,7313, proses pengolahan dilakukan dengan menggunakan tingkat kesalahan sebesar 0,05. Hasil yang diperoleh didalam pengujian Hausman Test menunjukan bahwa nilai prob sebesar $0,7313 \geq$ alpha 0,05 . Berdasarkan hasil pengujian random test dapat disimpulkan bahwa penggunaan random effect 
model dalam pembentukan regresi panel dapat diterima dan layak digunakan dalam pembentukan model terbaik.

\section{PENGUJIAN HIPOTESIS}

Tabel 3

Hasil Pengujian Koefisien Determinasi (R-square)

\begin{tabular}{|l|c|}
\hline \multicolumn{1}{|c|}{ Keterangan } & Koefisien \\
\hline$R$-Square & 0,0596 \\
\hline Adjust $R$-Square & 0,0403 \\
\hline
\end{tabular}

Sumber Hasil Pengolahan Data Eviews 2019

Berdasarkan tabel 3 hasil pengujian koefisien determinasi diperoleh nilai Adjust R-square sebesar 0,0403 hasil yang diperoleh tersebut mengisyaratkan bahwa variabel Kepemilikan Keluarga, Kepemilikan Institusional dan dewan komisaris independen variasi kontribusi dalam mempengaruhiBiaya Ekuitas sebesar 4,03\% sedangkan sisanya 95.97\% lagi dijelaskan oleh variabel lain yang belum digunakan didalam penelitian saat ini.

Berdasarkan hasil pengujian t-statistik yang telah dilakukan diperoleh ringkasan hasil terlihat pada tabel 4 dibawah ini:

\section{Tabel 4}

\section{Hasil Pengujian Hipotesis}

\begin{tabular}{|l|c|c|c|c|c|c|}
\hline $\begin{array}{c}\text { Variabel } \\
\text { Penelitian }\end{array}$ & Koefisien & t-hit & t-tabel & Signifikansi & Alpha & Kesimpulan \\
\hline C & 1,306 & & & & & \\
\hline $\begin{array}{l}\text { Kepemilikan } \\
\text { Keluarga }\end{array}$ & $-0,008$ & $-0,546$ & $-1,976$ & 0,585 & 0,05 & $\begin{array}{c}\text { H1 } \\
\text { Ditolak }\end{array}$ \\
\hline $\begin{array}{l}\text { Kepemilikan } \\
\text { Institusional }\end{array}$ & 0,005 & $-2,771$ & $-1,976$ & 0,006 & 0,05 & $\begin{array}{c}\text { H2 } \\
\text { Diterima }\end{array}$ \\
\hline Dewan & $-0,010$ & - & - & 0,298 & 0,05 & H3 \\
\hline
\end{tabular}




\begin{tabular}{|l|l|l|l|l|l|l|}
\hline $\begin{array}{l}\text { Komisaris } \\
\text { Independen }\end{array}$ & & 1,043 & 1,976 & & & Ditolak \\
\hline
\end{tabular}

Sumber Hasil Pengolahan Data Eviews 2019

Berdasarkan tabel 4 dapat diturunkan persamaan model analisis regresi panel adalah

$$
C O E=1,306-0,008 K K_{i t}+0,005 K I_{i t}-0,010 D K I_{i t}+e
$$

Pada model regresi panel terlihat nilai konstanta yang dihasilkan adalah sebesar 1,306 nilai yang diperoleh tersebut mengisyaratkan bahwa jika diasumsikan tidak terjadi perubahan (peningkatan atau penurunan) variabel kepemilikan keluarga, kepemilikan institusional dan dewan komisaris independen maka nilai dari variabel biaya ekuitas adalah sebesar 1,306.

Model persamaan regresi panel juga terlihat bahwa variabel kepemilikan keluar amemiliki nilai koefisien regresi bertanda negatif sebesar 0,008. Nilai koefisien yang diperoleh menunjukkan bahwa ketika diasumsikan terjadi peningkatan kepemilikan keluarga yang dimiliki perusahaan sebesar $1 \%$ akan menurunkan biaya ekuitas sebesar 0,008 dengan asumsi faktor lain selain kepemilikan keluarga dianggap tetap atau konstan.

Variabel kedua kepemilikan institusional memiliki koefisien regresi bertanda positif sebesar 0,005 nilai koefisien yang diperoleh menunjukkan bahwa ketika diasumsikan terjadi peningkatan kepemilikan Institusional sebesar 1\% akan mendorong meningkatkan biaya ekuitas pada perusahaan sebesar $0,005 \%$ dengan asumsi faktor lain selain kepemilikan institusional dianggap konstan atau tetap. 
Variabel terakhir dewan komisaris independen memiliki koefisien regresi bertanda negatif sebesar 0,010 dengan nilai koefisien yang diperoleh menunjukkan ketika diasumsikan terjadi peningkatan dewan komisaris independen di dalam perusahaan sebesar $1 \%$ akan mendorong menurunnya biaya ekuitassebesar 0,010 dengan asumsi faktor lain selain dewan komisaris independen dianggap tetap atau konstan.

\section{PENGARUH KEPEMILIKAN KELUARGA TERHADAP BIAYA EKUITAS}

Berdasarkan hasil pengujian hipotesis pertama dengan menggunakan variabel kepemilikan Keluarga yang diukur dengan persentase Kepemilikan Keluarga dapat disimpulkan bahwa Kepemilikan Keluarga tidak berpengaruh terhadap Biaya Ekuitas

Berdasarkan hasil pengujian dapat diinterpretasikan bahwa kepemilikan keluarga didalam perusahaan manufaktur yang go public bukanlah variabel yang akan mendorong peningkatan estimasi dalam memprediksi biaya ekuitas dengan menggunakan model ohlson. Kondisi ini terjadi karena persentase kepemilikan keluarga didalam perusahaan yang dijadikan sampel relatif kecil atau kurang dari 20\% akibatnya peran yang dimiliki oleh pihak keluarga didalam perusahaan untuk meningkatkan atau menurunkan penggunaan ekuitas menjadi tidak terlihat, dalam hal ini peningkatan penggunaan modal dari pemilik lebih disebabkan oleh kebijakan perusahaan yang berhubungan dengan ekspansi atau investasi diluar kegiatan operasional, seperti 
melakukan merger, akuisisi, pembukaan kantor operasional baru dan sebagainya.

Temuan yang diperoleh didalam tahapan pengujian hipotesis tidak konsisten dengan beberapa hasil penelitian terdahulu yang telah dilakukan oleh yang membuktikan bahwa kepemilikan keluarga memiliki pengaruh signifikan positif terhadap biaya ekuitas perusahaan. Yao dan Sun yang menyatakan bahwa perusahaan dengan kepemilikan keluarga sebagai pemegang saham mayoritas memiliki biaya ekuitas yang lebih tinggi dibandingkan perusahaan lainnya. ${ }^{22}$ Guedhami dan Mishra ${ }^{23}$ yang membuktikan bahwa Excess control yang ditemukan dalam perusahaan keluarga menyebabkan turunnya nilai perusahaan sehingga biaya ekuitas perusahaan pun akan meningkat.

\section{PENGARUH KEPEMILIKAN INSTITUSIONAL TERHADAP BIAYA EKUITAS}

Variabel Kepemilikan Institusional yang diukur dengan persentase Kepemilikan Institusional diperoleh hasil pengujian bahwa kepemilikan Institusional berpengaruh positif terhadap Biaya Ekuitas.

Berdasarkan hasil pengujian dapat diinterpretasikan bahwa keberadaan struktur kepemilikan institusional mampu meningkatkan kinerja pasar, tetapi peningkatan kinerja pasar saham justru akan

${ }^{22}$ J. Yao, dan S. Y. Sun, "Ownership Structure and Cost of Equity Capital in East Asian Corporations", School of Accounting and Finance, The Hong Kong Polytechnic University, (2008).

${ }^{23}$ O. Guedhami, dan D. Mishra, "Excess control, Corporate Governance , and Implied Cost of Equity: An International Evidence", The Financial Review, 44(4), (2006), 489-524. 
mengurangi informasi yang harus diungkap perusahaan, sehingga berdampak terhadap turunnya biaya yang dikeluarkan perusahaan untuk kepentingan publik. Di samping itu investor institusional tidak ingin reputasinya turun, karena asimetri informasi bisa berakibat fatal terhadap pasar saham perusahaan yaitu ruginya para pemegang saham yang disebabkan pemegang saham minoritas dan pasar saham mendiskon harga pasar saham perusahaan. Kepemilikan institusional dapat digunakan untuk mengendalikan pihak manajemen melalui proses monitoring secara efektif dan efisien maka dapat mengurangi earning management dan meningkatkan kualitas laba yang dilaporkan.

Hasil ini sesuai dengan pernyataan yang dilakukan oleh Ashbough ${ }^{24}$ dan Sari ${ }^{25}$ yang mengatakan bahwa adanya struktur kepemilikan institusional yang dimiliki perusahaan menurunkan biaya ekuitas yang disajikan didalam menyampaikan informasi kepada publik. Adanya kepentingan pribadi yang dilakukan pemegang saham dalam mengeluarkan biaya ekuitas. Selain itu juga didukung oleh Susanto ${ }^{26}$ bahwa pemilik institusional sebagai pemegang saham mayoritas bisa menekan manajer untuk memberi informasi yang akurat tentang kondisi perusahaan walaupun perlu biaya besar.

${ }^{24}$ H. Ashbough, D. W. Collins, dan L. Ryan, Collins, "Corporate Governance and the Cost of Equity Capital"(October, 2004).

${ }^{25}$ P. A. Sari, "Pengaruh Struktur Corporate Governance terhadap Cost of Equity Capital”, (2009).

${ }^{26}$ Susanto, "Struktur Kepemilikan Saham dan Kondisi Keuangan Perusahaan Pengaruhnya Terhadap Kebijakan Hutang (Studi pada Perusahaan Manufaktur di Pasar Modal Indonesia)", Neo-Bisnis, 5(1), (2011). 


\section{PENGARUH DEWAN KOMISARIS INDEPENDEN TERHADAP BIAYA EKUITAS}

variabel dewan komisaris independen yang diukur dengan persentase jumlah komisaris independen, diperoleh bahwa dewan komisaris independen tidak berpengaruh terhadap Biaya Ekuitas.

Berdasarkan hasil pengujian dapat diinterpretasikan bahwa keberadaan dewan komisaris independen didalam perusahaan manufaktur bukanlah variabel yang dapat memberikan peningkatan atau penurunan terhadap biaya ekuitas. Pengelolaan dewan komisaris independen dalam memberikan pengawasan didalam perusahaan belum cukup untuk memberikan pengaruh dalam memprediksi biaya ekuitas dengan menggunakan model Ohlson. Seharusnya Penerapan corporate governance yang baik akan menghasilkan biaya ekuitas yang lebih rendah melalui pengurangan biaya monitoring yang dilakukan oleh investor. Hal ini disebabkan investor harus mengeluarkan biaya monitoring untuk memastikan hasil yang diberikan oleh manajemen perusahaan akibat adanya asimetri informasi. Hasil ini menunjukkan kemungkinan banyak pengeluaran modal yang dilakukan perusahaan tidak mampu memberikan monitoring dan pengawasan yang optimal, sehingga memerlukan biaya yang cukup besar dalam melakukan expansi

Hasil penelitian sesuai dengan Sari dan Diyanty ${ }^{27}$, dan Ashbough ${ }^{28}$ menurunnya tingkat resiko yang dihadapi oleh investor dengan

27 I. C.Sari, dan V.Diyanty, Pengaruh Efektifitas Dewan Komisaris dan Pengendali Keluarga Terhadap Biaya Ekuitas, (2014)

${ }^{28}$ H. Ashbough, D. W. Collins, dan L. Ryan, Collins, "Corporate Governance and the Cost of Equity Capital”, (October, 2004). 
adanya penerapan corporate governance yang baik dalam perusahaan, maka perusahaan semakin mudah dalam memperoleh dana pembiayaan kegiatan operasionalnya,

\section{KESIMPULAN}

Berdasarkan hasil pengujian dapat disimpulkan bahwa (1) Kepemilikan Keluarga tidak berpengaruh terhadap biaya Ekuitas, (2) Kepemilikan Institusional berpengaruh positif terhadap biaya ekuitas, (3) Dewan Komisaris Independen tidak berpengaruh terhadap biaya ekuitas.

\section{DAFTAR RUJUKAN}

Anderson, R. C., Mansi, S., \& Reeb, D. M. "Founding Family Ownership and the Agency Cost of Debt". Ssrn, 2002.

Arifin. "Peran Akuntan dalam Menegakkan Prinsip Good Corporate Governance pada Perusahaan di Indonesia (Tinjauan Perspektif Teori Keagenan)". Jurnal Ekonomi Universitas Diponegoro, 2005.1-52.

Ashbough, H., Collins, D. W., \& Ryan, L. Corporate Governance and the Cost of Equity Capital. SSRN Electronic Journal, October 2004.

Chancera, D. M. "Biaya Modal Ekuitas Pada Perusahaan Manufaktur yang Terdaftar di Bursa Efek Indonesia ( BEI ) Tahun 20082009". Skripsi Fakultas Ekonomi Universitas Diponegoro, 2011.

Guedhami, O., \& Mishra, D. "Excess control, Corporate Governance , and Implied Cost of Equity: An International Evidence". The 
Financial Review, 44(4), 2006.

Herawati. Akuntansi Biaya LKMS. Padang: Universitas Bung Hatta Press, 2008.

Jensen, M. C., \& Meckling, W. H. "Theory of the firm: Managerial behavior, agency costs and ownership structure". Journal of Financial Economics, 3(4), 1976.

Juniarti, \& Sentosa, A. A. "Pengaruh Good Corporate Governance, Voluntary Disclosure terhadap Biaya Hutang (Costs of Debt)". Jurnal Akuntansi dan Keuangan, 11(2), 2009.

Mansuri. Modul Praktikum Eviews Analisis Regresi Linier Berganda Menggunakan Eviews, 2016.

Peraturan Ototitas Jasa Keuangan No.33. "Direksi dan Dewan Komisaris Emiten atau Perusahaan Publik. Nomor 33 /Pojk.04/2014". Jakarta: Republik Indonesia, 2014.

Rad, S. A. "The relationship between corporate governance practices and cost of capital in large listed companies of New Zealand and Singapore". Journal of Economy The University of Waikato, 1994.

Rebecca, Y., \& Siregar, S. V. "Pengaruh Corporate Governance Index, Kepemilikan Keluarga, dan Kepemilikan Institiusional terhadap Biaya Ekuitas dan Biaya Utang: Studi Empiris pada Perusahaan Manufaktur yang Terdaftar di BEI". Simposium Nasional Akuntansi 13, 2004.

Rivandi, M. "Pengaruh Enterprise Risk Management Disclosure Dan Corporate Governance Terhadap Nilai Perusahaan". Jurnal Benefita, 3(2), 2018. 
Sari, I. C., \& Diyanty, V. "Pengaruh Efektifitas Dewan Komisaris dan Pengendali Keluarga Terhadap Biaya Ekuitas". Jurnal Ekonomi Universitas Indonesia, 2014.

Sari, P. A. "Pengaruh Struktur Corporate Governance Terhadap Cost of Equity Capital". Skripsi Fakultas Ekonomi Universitas Sebelas Maret Surakarta, 2009.

Susanto, H. "Struktur Kepemilikan Saham dan Kondisi Keuangan Perusahaan Pengaruhnya Terhadap Kebijakan Hutang (Studi pada Perusahaan Manufaktur di Pasar Modal Indonesia)". NeoBisnis, 5(1), 2011.

Tarjo. "Pengaruh Konsentrasi Kepemilikan Institusional dan Leverage terhadap Manajemen Laba, Nilai Pemegang Saham serta Cost of Equity Capital". Jurnal Ekonomi Universitas Trunojoyo Bangkalan Madura, 2006.

Winarno, W. Operational Eviews. Jakarta: Salemba Empat, 2009.

Yao, J. ., \& Sun., S. Y. "Ownership Structure and Cost of Equity Capital in East Asian Corporations". School of Accounting and Finance, The Hong Kong Polytechnic University, 2008. 